\title{
Selection and Evaluation of Appropriate Reference Genes for RT-qPCR Normalization of Volvariella volvacea Gene Expression under Different Conditions
}

\author{
Jiang Qian $\mathbb{D}^{1},{ }^{1}$ Yingnv Gao, ${ }^{2}$ Ying Wáng $\mathbb{D}^{2},{ }^{2}$ Yingying Wu, ${ }^{2}$ Ying Wāng $\mathbb{D}{ }^{2}$ \\ Yucheng Zhao $\mathbb{D},{ }^{3}$ Hongyu Chen, ${ }^{2}$ Dapeng Bao, ${ }^{2}$ Jiyang Xu $\mathbb{D}^{1},{ }^{1}$ and Xiaohong Bian $\mathbb{D}^{1}$ \\ ${ }^{1}$ School of Life Science and Technology, China Pharmaceutical University, No. 24, Tongjiaxiang, Gulou District, Nanjing 210009, China \\ ${ }^{2}$ National Engineering Research Center of Edible Fungi and Key Laboratory of Applied Mycological Resources and Utilization, \\ Ministry of Agriculture and Shanghai Key Laboratory of Agricultural Genetics and Breeding and Institute of Edible Fungi, \\ Shanghai Academy of Agriculture Science, Shanghai, China \\ ${ }^{3}$ Jiangsu Key Laboratory of Bioactive Natural Product Research and State Key Laboratory of Natural Medicines, \\ China Pharmaceutical University, Nanjing, Jiangsu, China
}

Correspondence should be addressed to Jiyang Xu; jiyangx@126.com and Xiaohong Bian; xh_bian@163.com

Received 24 January 2018; Accepted 10 June 2018; Published 9 July 2018

Academic Editor: Hely M. Häggman

Copyright ( 2018 Jiang Qian et al. This is an open access article distributed under the Creative Commons Attribution License, which permits unrestricted use, distribution, and reproduction in any medium, provided the original work is properly cited.

Volvariella volvacea (V. volvacea), commonly referred to as Chinese (paddy straw) mushroom, is a basidiomycete with a proteinrich volva and pileus. Selecting appropriate reference genes is a crucial step in the normalization of quantitative real-time PCR data. Therefore, 12 candidate reference genes were selected from the $V$. volvacea transcriptome based on previous studies and then BestKeeper, geNorm, and NormFinder were used to identify reference genes stably expressed during different developmental stages and conditions. Of the 12 candidate reference genes, SPRY domain protein (SPRYp), alpha-tubulin (TUB $\alpha)$, cyclophilin (CYP), Lasparaginase ( $L$-asp), and MSF1-domain-containing protein (MSF1) were the most stably expressed under different experimental conditions, while $18 \mathrm{~S}$ ribosomal RNA (18S), $28 \mathrm{~S}$ ribosomal RNA (28S), and beta-actin (ACTB) were the least stably expressed. This investigation not only revealed potential factors influencing the suitability of reference genes, but also identified optimal reference genes from a pool of candidate genes under a wide range of conditions.

\section{Introduction}

Quantitative real-time PCR (RT-qPCR) has emerged as a powerful and popular tool used for rapid and accurate assessment of changes in gene expression [1-3]. The reliability of gene expression measurements by RT-qPCR is strongly affected by technical factors, including template RNA quality, efficiency of complementary DNA (cDNA) synthesis, performance of primers, and normalization [4-6]. When normalizing target gene expression, selecting a stable reference gene is extremely important, especially for samples with fluctuating expression levels $[7,8]$. The use of unsuitable reference genes in RT-qPCR analysis has yielded unreliable and confusing results $[9,10]$. Certain reports have supported merging expression of at least three reference genes when normalizing RT-qPCR results [11, 12]. In addition, the same reference genes often cannot be used for different tissues and cells, even when the samples are derived from the same species. Therefore, selection of suitable reference genes based on a given experimental design or species is necessary [13, 14].

Volvariella volvacea (Bull.) Singer, i.e., straw mushroom or Chinese mushroom, is the world's third largest edible fungus and is a tropical and subtropical saprophytic fungus in the Pluteaceae family and Basidiomycota phylum [15-17]. This mushroom is an important healthy food source and valuable supplement with dietary and medicinal attributes due to being rich in certain nutrients, including proteins, vitamins, fats, and amino acids [18]. V. volvacea is the fastest growing species of edible fungi, requiring only 7 to 12 days from sowing to fruiting and 30 days to cultivation. In addition, 
it has a high economic efficiency owing to only requiring a simple planting method and ample availability of raw materials $[17,19]$. Filamentous fungi are important organisms frequently studied by RT-qPCR; however, identification of suitable reference genes for RT-qPCR of fungal species has received little attention. Published reports on fungal internal control genes have mainly focused on relative expression stability [20-22] and failed to evaluate absolute expression levels. Moreover, these studies have mostly involved traditional housekeeping genes in Ascomycetes [20, 21, 23-25], with the exception of studies on Phakopsora pachyrhizi [26, 27] and Pleurotus ostreatus [28]. Little information is currently available on Basidiomycetes reference genes.

Traditionally, 18S ribosomal RNA (18S), $28 \mathrm{~S}$ ribosomal RNA (28S), $\beta$-actin (ACTB), cyclophilin (CYP), tubulin (TUB $\alpha$ and $T U B \beta 1$ ), glyceraldehyde-3-phosphate dehydrogenase $(G A P D H)$, and ubiquitin $(U B Q)$, genes with housekeeping roles in basic cellular processes, have been used as reference genes $[29,30]$. However, the stability of these housekeeping genes can restrict experimental design or the use of certain treatments. In addition, different materials tend to have different genes that are stable and expression levels may differ under different experimental conditions [30, 31].

In this study, we selected 12 candidate reference genes based on $V$. volvacea transcriptome RNA-seq datasets. The expression of these candidate reference genes following different treatments was profiled. The stability of expression of these genes was further validated using RT-qPCR and statistical algorithms, including geNorm, NormFinder, and BestKeeper. Comprehensive ranking of the stability of these reference genes under each specific experimental condition was also performed.

\section{Materials and Methods}

2.1. Sample Preparation and Treatment. V. volvacea homokaryon PYd15 (ACCC52631) was obtained from the Shanghai Academy of Agricultural Science and maintained on potato dextrose agar at $32^{\circ} \mathrm{C}$ with periodic transfers. Mycelial samples of this strain were cultivated in potato dextrose medium with shaking at $150 \mathrm{rpm}$ at $32^{\circ} \mathrm{C}$ and incubated in the absence or presence of $\mathrm{NaCl}, \mathrm{CuSO} 4, \mathrm{H}_{2} \mathrm{O}_{2}, \mathrm{HCl}, \mathrm{NaOH}$, heat, or cold for four days. For fruiting body production, solid cultures of the strain were cultivated on rice straw compost as described by Chen et al. [32]. Fruiting body samples were harvested at the primordium and fruiting developmental stages according to Tao et al. [29]. The entire fruiting body was harvested, chopped, and then mixed. Each sample was prepared using a mixture of multiple fruiting bodies. All samples were immediately frozen in liquid nitrogen and then RNA was extracted. Three independent biological replicates were tested for each sample and all samples in each biological replicate were harvested from a newly produced batch.

2.2. Isolation of Total RNA and cDNA Synthesis. Total RNA was extracted from samples using an RNAprep Pure Plant Kit (Tiangen Biotech, Beijing, China), treated with DNase I (Ambion, USA) to digest contaminating DNA, and then purified according to the manufacturer's protocol. The integrity of the RNA was verified by electrophoresis on $1.5 \%(\mathrm{w} / \mathrm{v})$ agarose gels and the quantity and quality of the RNA were measured using a NanoDrop 2000 Spectrophotometer (NanoDrop Technologies, Thermo Scientific, USA). Only RNA samples with absorption ratios of A260/280 ranging from 1.8 to 2.2 and $A 260 / 230>1.8$ were used for $\mathrm{CDNA}$ synthesis.

The cDNA was synthesized from $1 \mu \mathrm{g}$ total RNA in a final volume of $20 \mu \mathrm{L}$ using the PrimeScriptTM RT reagent Kit with gDNA Eraser (TaKaRa Bio Inc., Dalian, China) according to the manufacturer's instructions and then diluted 10 -fold with nuclease-free water for RT-qPCR.

2.3. Selection and Validation of Candidate Reference Genes and Primer Design. Based on previous studies, the expression stability of the 12 candidate genes $A C T B, C Y P, G A P D H$, TUB $\alpha, T U B \beta 1, U B Q, M S F 1, S P R Y p, L$-asp, MAPK, 18S, and $28 S$, described in Table 1, was assessed to identify the most stable $V$. volvacea reference genes under different conditions. The primers were designed using Primer Premier 5.0 based on the following criteria: primer length of 20-27 bp, GC content of $45-55 \%$, melting temperature ranging from 55 to $60^{\circ} \mathrm{C}$, and amplicon length of 100-250 bp.

2.4. Amplification by RT-qPCR. Gene expression levels were examined by RT-qPCR on an Applied Biosystems 7500 RealTime PCR system. Each reaction mixture contained $2 \mu \mathrm{l}$ prepared cDNA template, $0.4 \mu \mathrm{l}$ each forward, and reverse primers $(10 \mathrm{nM}), 6.8 \mu \mathrm{l}$ of $\mathrm{ddH}_{2} \mathrm{O}, 0.4 \mu \mathrm{l}$ ROX, and $10 \mu \mathrm{l}$ of Power SYBR Green PCR Master Mix (Life Technologies, USA) in a final volume of $20 \mu \mathrm{l}$. Amplification cycles involved an initial denaturation step at $95^{\circ} \mathrm{C}$ for $5 \mathrm{~min}$, followed by 40 cycles of $95^{\circ} \mathrm{C}$ for $15 \mathrm{~s}$ and $60^{\circ} \mathrm{C}$ for $1 \mathrm{~min}$. A temperature ramp step with an initial temperature of $60^{\circ} \mathrm{C}$ and final temperature of $95^{\circ} \mathrm{C}$ was performed following the amplification for dissociation analysis. Each biological sample was tested in triplicate.

2.5. Gene Expression Stability Analysis. To analyze the expression stability of candidate reference genes, geNorm [33], NormFinder [34], and BestKeeper [35] were used based on the experimental design and manufacturers' instructions. For geNorm and NormFinder analysis, the raw $\mathrm{Cp}$ values were transformed into relative quantities using the formula $2^{-\Delta C T}$ $(\Delta \mathrm{CT}=$ each corresponding $\mathrm{Ct}$ value - same gene's lowest $\mathrm{Ct}$ value in different samples, where $\mathrm{Cp}$ is an alternative designation for $\mathrm{Ct}$ ). These values were imported into geNorm to obtain a gene expression stability value (M). Similar to geNorm, NormFinder was used to further investigate the expression stability values (M) for each gene and the pairwise variation $(\mathrm{V})$ of that gene against other reference genes was evaluated. The reference gene with the highest $M$ was considered to have the most unstable expression, while the lowest $\mathrm{M}$ indicated the most stable expression. BestKeeper analysis used the untransformed Cps, the coefficients of variance (CVs), and the standard deviations (SDs) of the Cps to evaluate the stability of the reference genes. BestKeeper was also used to rank candidate expression from the most to least stable. By combining these three types of Microsoft Excel-based software, the expression stability of the 


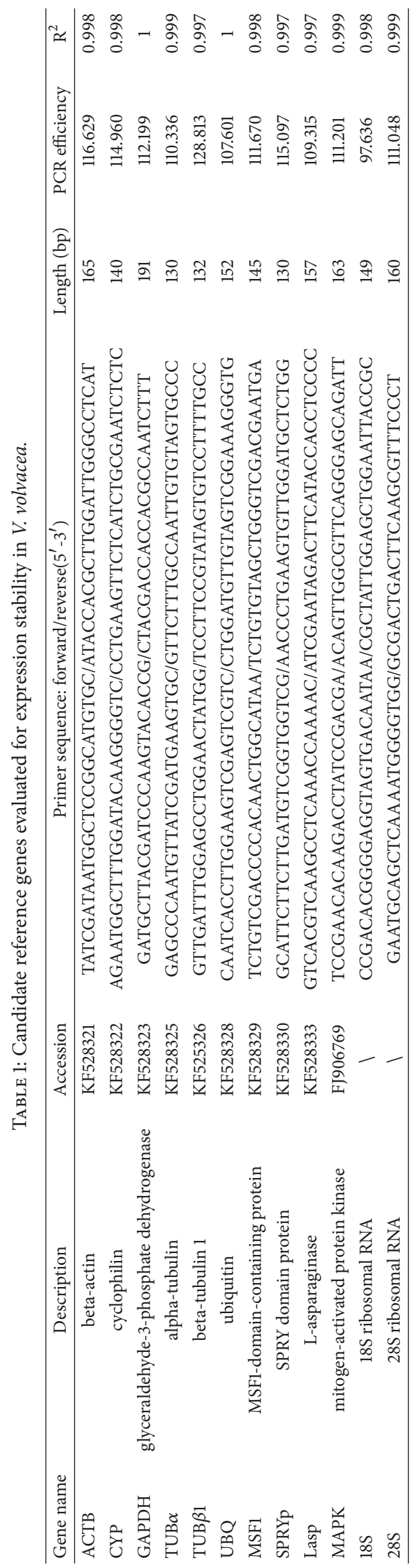


candidate reference genes under different conditions was easily ranked.

2.6. Statistical Analysis. The RT-qPCR data was obtained from three biological replicates tested in triplicate. Unless indicated otherwise, data are presented as mean \pm standard error of the mean. Statistical analyses were performed using Student's t-test. Graphs were generated using GraphPad Prism 6 (GraphPad Software, Inc., La Jolla, CA, USA). Data analysis was performed using geNorm [33], NormFinder [34], and BestKeeper [35] according to the manufacturers' instructions.

\section{Results}

3.1. Selection of Candidate Reference Genes, Specificity of Amplification, and PCR Efficiency. Gene names, descriptions, accession numbers, primer sequences, PCR product lengths, PCR efficiencies, and regression coefficients for the 12 candidate genes are listed in Table 1 . The gene sequences of beta-actin (ACTB), cyclophilin (CYP), glyceraldehyde-3phosphate dehydrogenase (GAPDH), alpha-tubulin $(T U B \alpha)$, beta-tubulin 1 (TUBß1), ubiquitin (UBQ), MSF1-domaincontaining protein (MSFI), SPRY domain protein (SPRYp), L-asparaginase $(L$-asp), mitogen-activated protein kinase (MAPK), and 18S (18S) and 28S ribosomal RNA (28S) were identified in the $V$. volvacea genome and confirmed by NCBI BLAST. The expression stability of these genes was assessed under various conditions, including in the presence of abiotic stresses $\left(\mathrm{NaCl}, \mathrm{CuSO}_{4}, \mathrm{H}_{2} \mathrm{O}_{2}, \mathrm{HCl}, \mathrm{NaOH}\right.$, heat, and cold) and different developmental stages. To calculate the amplification efficiency, standard curves were generated for the candidate genes using 10 -fold serial dilutions of plasmid DNA containing the given genes. Based on the slopes of the standard curves (Fig. S3), PCR efficiencies (E) and regression coefficients (R2) were calculated and are listed in Table 1 and Fig. S3, respectively. Briefly, the $\mathrm{R}^{2}$ for all primers was $>0.99$ and the $\mathrm{E}$ ranged from $97.636 \%$ to $128.813 \%$.

\section{Expression Profiles of the Candidate Reference Genes}

To evaluate the stability of the reference genes in all experimental samples, the transcript abundances of the 12 candidate reference genes were measured based on their mean cycle threshold values (Cps). The mean Cps ranged from 9 to 29 and most were between 18 and 23. Across all samples, $18 S$ was the most abundantly expressed gene with the lowest average $\mathrm{Cp}(9.37 \pm 1.82)$, followed by $28 S(10.96 \pm 2.04)$,

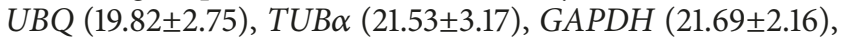
ACTB (21.89 \pm 2.35$),$ CYP $(22.13 \pm 1.43)$, TUB $\beta 1(23.55 \pm 3.30)$, SPRYP (25.73 \pm 2.47$), M S F 1$ (26.10 \pm 2.21$),$ MAPK (27.95 \pm 2.82$)$, and finally $L$-asp (29.56 \pm 2.17$)$. These Cps, as well as gene expression variation, are presented in Figure 1 using boxplots. Larger Cp SDs indicate more variable expression. CYP displayed the least variation in gene expression $(22.13 \pm 1.43)$, indicating that it is stably expressed under different conditions and could be the optimal reference gene. Meanwhile, MAPK had Cps ranging from 22.12 to 33.88 and should be

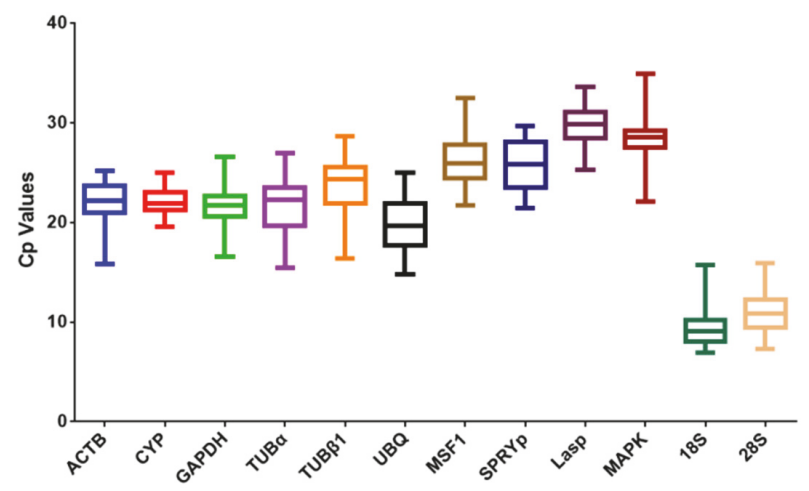

FIgURE 1: Comparison of transcript abundances of the 12 candidate reference genes. Boxes indicate the $25 \mathrm{th} / 75$ th percentiles, lines represent the median, and error bars represent the maximum and minimum $\mathrm{Cp}$ values. The 12 candidate reference genes are listed on the $\mathrm{x}$-axis.

avoided as a reference gene. In general, the Cps in boxplot form displayed the expression profiles of the reference genes and gave us a glimpse into gene stability. However, considering the complex surroundings of edible fungi, the stability of reference genes under different conditions needs to be investigated systematically (Figure 1).

4.1. Expression Stability of Candidate Reference Genes. In order to further evaluate the expression stability of candidate reference genes, $V$. volvacea was exposed to different stresses (salt, oxidative, heavy metal, acid-base, and temperature stresses) or collected at different developmental growth stages. Gene expression was evaluated in these samples (three biological and technical replicates for a total of $972 \mathrm{Cps}$ ) using three Excel-based programs, geNorm [33], NormFinder [34], and BestKeeper [35].

4.2. Analysis Using geNorm. Analysis with geNorm measures reference gene expression stability $(\mathrm{M})$ by calculating the pairwise variation for each reference gene against all other control genes and the SD of the logarithmically transformed expression ratios, where a high $\mathrm{M}$ means low stability [33]. For geNorm analysis, the Cps collected from the samples described above were processed on a linear scale using the $\Delta \mathrm{Cp}$ method [33]. As shown in Figure 2, different reference genes had different stabilities. The top two reference genes for RT-qPCR normalization were $T U B \alpha$ and $U B Q$ for salt stress, $T U B \alpha$ and $T U B \beta 1$ for oxidative stress, $C Y P$ and $U B Q$ for heavy metal stress, $M S F 1$ and $S P R Y p$ for cold stress, $U B Q$ and MSF1 for heat stress, SPRYP and MAPK for acid stress, $M S F 1$ and MAPK for alkali stress, and TUB $\beta 1$ and MAPK for different developmental stages. Across all samples, TUB $\alpha$ and $S P R Y p$ were the most stably expressed genes (Figure 2). Therefore, these two reference genes were deemed the best reference genes for the widest range of test conditions based on this present study.

4.3. NormFinder Analysis. NormFinder is an algorithm used to identify the optimal normalization gene in a given experimental design. Similar to geNorm, RT-qPCR data was 

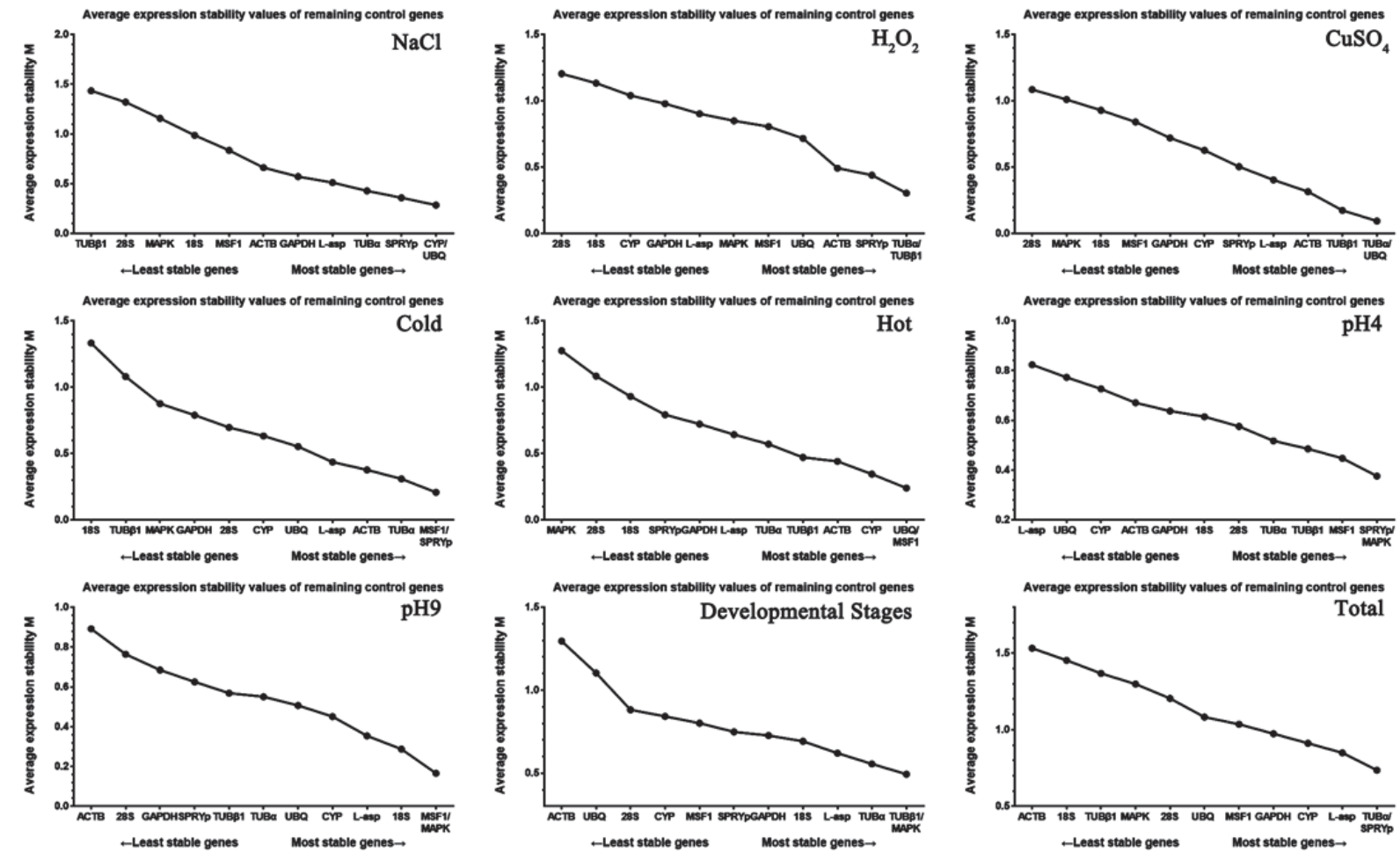

FIgURE 2: Expression stability of $\mathbf{1 2} \mathbf{V}$. volvacea candidate genes as predicted by geNorm analysis. Average expression stability (M) for each condition was calculated. The least stable gene with the highest $M$ value is on the left, while the most stable gene is on the right. The treatments and group classifications are indicated in the figure.

first transformed [34]. The gene stabilities calculated using NormFinder are presented in Table 2 with gradually decreasing stabilities presented going from the top to the bottom in ranking order. $U B Q, S P R Y p, M S F 1,18 S$, and $L$-asp were the most stable reference genes in the presence of $\mathrm{NaCl}$ (as well as $\mathrm{CuSO}_{4}$ and heat), $\mathrm{H}_{2} \mathrm{O}_{2}$, cold (as well as acid), alkalinity, and during different developmental stages, respectively. Among the most stable reference genes, $18 \mathrm{~S}$ had the lowest value and therefore could be considered the optimal reference gene. For all samples as a whole, SPRYp had the most stable expression. Interestingly, $U B Q$ ranked near the top for 3 out of 8 tested conditions, similar to the outcomes of geNorm analysis (Figure 2). However, there were also slight differences between the geNorm and NormFinder results. For instance, $L$-asp, CYP, and MSF1 were the third, fourth, and sixth most stable reference genes in geNorm (Figure 2), but the fourth, fifth, and third in NormFinder (Table 2), respectively. Therefore, an additional method of analysis was utilized to mediate these differences.

4.4. BestKeeper Analysis. BestKeeper is an Excel-based tool that uses pairwise correlations to determine the stability of housekeeping genes, differentially regulated target genes, and sample integrity [35]. The CVs and SDs of the candidate reference genes were used to evaluate the stability of the candidate reference genes in all tested conditions. The gene with the lowest CV and SD was considered the most stably expressed [36]. This method differs from the geNorm and
NormFinder analysis as it uses raw Cps for analysis. Similar to the results of NormFinder analysis, the $\mathrm{CV} \pm \mathrm{SD}$ rank of the candidate genes increased gradually, suggesting the stability decreased gradually. For example, MAPK had a $\mathrm{CV} \pm \mathrm{SD}$ value of $0.41 \pm 0.12$ and was the most stable gene under $\mathrm{H}_{2} \mathrm{O}_{2}$-induced oxidative stress, while $18 \mathrm{~S}$ was the least stable gene with a $\mathrm{CV} \pm \mathrm{SD}$ of $12.98 \pm 1.15$ (Figure 3 ). An $\mathrm{SD}>1$ was considered inconsistent and any such values should be excluded [14]; therefore, none of the reference genes could be used under all conditions, as the lowest SD in this scenario was 1.16. Fortunately, in another 8 groups or experimental conditions, nearly all SD values were below 1.16 , except for the most unstable one. Certain reference genes, namely, SPRYp, $M A P K$, and $L$-asp, had a tendency to be the most stable and were ranked among the top 3 reference genes. By contrast, $18 \mathrm{~S}$ and $28 S$ did not appear to be good reference genes.

\section{Comprehensive Stability Analysis of Reference Genes}

To obtain a consensus result of the most stable reference genes as recommended by the three methods, the geometric mean of three algorithms corresponding rankings for each candidate gene was calculated (Table 3). SPRYp, TUB $\alpha, C Y P$, $L$-asp, and $M S F 1$ were ranked as the top five stable reference genes in the all samples stress; MSF1 also comprehensively ranked first in the Cold and Hot stress subset. In $\mathrm{H}_{2} \mathrm{O}_{2}$ stress subset, $T U B \beta 1$ was stably expressed most. For both the $\mathrm{NaCl}$ 
TABLE 2: Expression stability of 12 V. volvacea reference genes as calculated by NormFinder.

\begin{tabular}{|c|c|c|c|c|c|c|c|c|c|}
\hline Rank & $\mathrm{NaCl}$ & $\mathrm{CuSO}_{4}$ & $\mathrm{H}_{2} \mathrm{O}_{2}$ & Heat & Cold & $\mathrm{pH} 4$ & $\mathrm{pH} 9$ & Developmental Stage & Total \\
\hline \multirow[t]{2}{*}{1} & UBQ & UBQ & SPRYp & UBQ & MSF1 & MSF1 & $18 \mathrm{~S}$ & L-asp & SPRYp \\
\hline & 0.244 & 0.105 & 0.164 & 0.033 & 0.070 & 0.132 & 0.029 & 0.287 & 0.354 \\
\hline \multirow[t]{2}{*}{2} & SPRYp & TUB $\alpha$ & TUB $\beta 1$ & MSF1 & SPRYp & TUB $\alpha$ & L-asp & TUB $\beta 1$ & TUB $\alpha$ \\
\hline & 0.253 & 0.18 & 0.269 & 0.083 & 0.072 & 0.226 & 0.139 & 0.288 & 0.373 \\
\hline \multirow[t]{2}{*}{3} & CYP & SPRYp & ACTB & CYP & TUB $\alpha$ & TUB $\beta 1$ & CYP & MAPK & MSF1 \\
\hline & 0.425 & 0.205 & 0.367 & 0.304 & 0.104 & 0.253 & 0.250 & 0.315 & 0.485 \\
\hline \multirow[t]{2}{*}{4} & L-asp & L-asp & TUB $\alpha$ & TUB $\beta 1$ & ACTB & ACTB & UBQ & $\mathrm{TUB} \alpha$ & L-asp \\
\hline & 0.524 & 0.288 & 0.403 & 0.399 & 0.365 & 0.365 & 0.267 & 0.316 & 0.553 \\
\hline \multirow[t]{2}{*}{5} & TUB $\alpha$ & TUB $\beta 1$ & UBQ & ACTB & L-asp & MAPK & MSF1 & GAPDH & CYP \\
\hline & 0.534 & 0.301 & 0.467 & 0.410 & 0.400 & 0.379 & 0.297 & 0.323 & 0.557 \\
\hline \multirow[t]{2}{*}{6} & $18 \mathrm{~S}$ & ACTB & MSF1 & TUB $\alpha$ & UBQ & SPRYp & MAPK & $18 \mathrm{~S}$ & GAPDH \\
\hline & 0.674 & 0.396 & 0.539 & 0.439 & 0.450 & 0.390 & 0.319 & 0.337 & 0.752 \\
\hline \multirow[t]{2}{*}{7} & ACTB & MSF1 & L-asp & SPRYp & CYP & GAPDH & TUB $\alpha$ & SPRYp & MAPK \\
\hline & 0.777 & 0.623 & 0.615 & 0.497 & 0.459 & 0.436 & 0.320 & 0.417 & 0.826 \\
\hline \multirow[t]{2}{*}{8} & GAPDH & $18 \mathrm{~S}$ & MAPK & GAPDH & $28 \mathrm{~S}$ & $28 \mathrm{~S}$ & TUB $\beta 1$ & MSF1 & UBQ \\
\hline & 0.803 & 0.669 & 0.645 & 0.637 & 0.550 & 0.473 & 0.365 & 0.423 & 0.831 \\
\hline \multirow[t]{2}{*}{9} & MSF1 & GAPDH & GAPDH & L-asp & MAPK & CYP & SPRYp & CYP & TUB $\beta 1$ \\
\hline & 0.872 & 0.805 & 0.853 & 0.671 & 0.625 & 0.480 & 0.498 & 0.455 & 0.838 \\
\hline \multirow[t]{2}{*}{10} & MAPK & CYP & $18 \mathrm{~S}$ & $18 \mathrm{~S}$ & GAPDH & $18 \mathrm{~S}$ & GAPDH & $28 \mathrm{~S}$ & $28 \mathrm{~S}$ \\
\hline & 0.945 & 0.816 & 0.872 & 0.883 & 0.902 & 0.490 & 0.601 & 0.577 & 0.843 \\
\hline \multirow[t]{2}{*}{11} & TUB $\beta 1$ & MAPK & CYP & $28 \mathrm{~S}$ & TUB $\beta 1$ & UBQ & $28 \mathrm{~S}$ & UBQ & $18 \mathrm{~S}$ \\
\hline & 1.221 & 0.843 & 0.899 & 1.142 & 1.315 & 0.544 & 0.769 & 1.237 & 1.041 \\
\hline \multirow[t]{2}{*}{12} & $28 \mathrm{~S}$ & $28 \mathrm{~S}$ & $28 \mathrm{~S}$ & MAPK & $18 \mathrm{~S}$ & L-asp & ACTB & ACTB & ACTB \\
\hline & 1.246 & 0.902 & 0.979 & 1.468 & 1.722 & 0.661 & 1.025 & 1.702 & 1.207 \\
\hline
\end{tabular}

stress subset and the $\mathrm{CuSO}_{4}$ stress subset, UBQ was the most stable gene. Additionally, under acid treatment, $M A P K$ was the best reference gene. The expression of $L$-asp was extremely stable under alkali stress and different developmental stages. $18 S$ and $28 S$ were unstably expressed in the majority of tested subsets. Owing to the geometric mean of three algorithms corresponding rankings, the results were more intuitive.

5.1. Optimal Number of Reference Genes for Accurate Normalization. In addition to using average pairwise expression ratios $(\mathrm{M})$ to evaluate gene expression stability, geNorm can also be used to determine the optimal number of reference genes for normalization, where pairwise variation $(\mathrm{Vn} / \mathrm{Vn}+1)$ between the normalization factors is calculated for all samples and 0.15 is the proposed cut-off [33]. Based on this, the pairwise variations were calculated and are listed in Figure 4. As indicated, the two most stable reference genes were sufficient for reliable normalization under all conditions, except during different developmental stages, and an additional reference gene was unnecessary. However, three genes were necessary for normalization when evaluating different developmental stages because V2/3>0.15. While including a third reference gene may increase the credibility of RT-qPCR analysis, the proposed 0.15 value should not be considered a strict cut-off in most cases, because using a combination of the two best reference genes was reliable enough for normalization [33], which is supported by the results of this study.
5.2. Reference Gene Validation. To evaluate the reliability of the selected reference genes, the relative expression levels of G6PDH were calculated. As depicted in Figure 5(a), enhanced expression of G6PDH was observed when normalized with the most stable reference gene, SPRYp. Meanwhile, when 28S, one of the least stable reference genes, was used, a notable reduction in expression was observed. To further evaluate the reliability of the selected reference genes, another stimulus was imposed and the three most stable reference genes were used to analyze the expression of G6PDH. The expression of $G 6 P D H$ was enhanced to the same level when normalized with no significant differences between reference genes (Figure 5(b)). However, a significant difference $(\mathrm{P}<0.01)$ between reference genes was observed in $G 6 P D H$ expression when using $28 \mathrm{~S}$, one of the most unstable reference genes. Using geNorm, the optimal number of reference genes for use in normalization was also investigated. While $28 \mathrm{~S}$ was not a suitable reference gene, the accuracy of the results became satisfactory when normalization was performed using $28 \mathrm{~S}$ in combination with other stable genes (Figure 5(c)).

\section{Discussion}

Due to its high sensitivity and specificity, RT-qPCR is now commonly used in many laboratories for high-throughput analysis of gene transcription. Utilizing suitable reference genes is necessary to ensure the reliability and accuracy of 
TABLE 3: Expression stability ranking of the 12 candidate reference genes.

\begin{tabular}{|c|c|c|c|c|c|c|c|c|c|c|c|c|}
\hline Method & 1 & 2 & 3 & 4 & 5 & 6 & 7 & 8 & 9 & 10 & 11 & 12 \\
\hline \multicolumn{13}{|c|}{ RANKING ORDER UNDER NaCl STRESS (BETTER-GOOD-AVERAGE) } \\
\hline geNorm & $\begin{array}{l}\text { CYP } \\
\text { UBQ }\end{array}$ & & SPRYp & TUB $\alpha$ & L-asp & GAPDH & ACTB & MSF1 & $18 \mathrm{~S}$ & MAPK & $28 \mathrm{~S}$ & TUB $\beta 1$ \\
\hline NormFinder & UBQ & SPRYp & CYP & L-asp & TUB $\alpha$ & $18 \mathrm{~S}$ & ACTB & GAPDH & MSF1 & MAPK & TUB $\beta 1$ & $28 \mathrm{~S}$ \\
\hline BestKeeper & SPRYp & UBQ & MAPK & L-asp & MSF1 & CYP & TUB $\alpha$ & АCTB & TUB $\beta 1$ & GADPH & $18 \mathrm{~S}$ & $28 \mathrm{~S}$ \\
\hline Comprehensive Ranking & UBQ & SPRYp & CYP & L-asp & $\operatorname{TUB} \alpha$ & MAPK & MSF1 & ACTB & GAPDH & $18 \mathrm{~S}$ & TUB $\beta 1$ & $28 \mathrm{~S}$ \\
\hline \multicolumn{13}{|c|}{ RANKING ORDER UNDER $\mathrm{H}_{2} \mathrm{O}_{2}$ STRESS (BETTER-GOOD-AVERAGE) } \\
\hline geNorm & $\begin{array}{c}\text { TUB } \alpha \\
\text { TUB } \beta 1\end{array}$ & & SPRYp & ACTB & UBQ & MSF1 & MAPK & L-asp & GAPDH & CYP & $18 \mathrm{~S}$ & $28 \mathrm{~S}$ \\
\hline NormFinder & SPRYp & TUB $\beta 1$ & ACTB & TUB $\alpha$ & UBQ & MSF1 & L-asp & MAPK & GAPDH & $18 \mathrm{~S}$ & CYP & $28 \mathrm{~S}$ \\
\hline BestKeeper & MAPK & MSF1 & UBQ & SPRYp & TUB $\beta 1$ & L-asp & ACTB & TUB $\alpha$ & CYP & GADPH & $28 \mathrm{~S}$ & $18 \mathrm{~S}$ \\
\hline Comprehensive Ranking & TUB $\beta 1$ & SPRYp & $\operatorname{TUB} \alpha$ & MAPK & MSF1 & UBQ & АСТВ & L-asp & GAPDH & CYP & $18 \mathrm{~S}$ & $28 \mathrm{~S}$ \\
\hline \multicolumn{13}{|c|}{ RANKING ORDER UNDER CuSO 4 STRESS (BETTER-GOOD-AVERAGE) } \\
\hline geNorm & $\begin{array}{l}\text { TUB } \alpha \\
\text { UBQ }\end{array}$ & & TUB $\beta 1$ & ACTB & L-asp & SPRYp & CYP & GAPDH & MSF1 & $18 \mathrm{~S}$ & MAPK & $28 \mathrm{~S}$ \\
\hline NormFinder & UBQ & $\operatorname{TUB} \alpha$ & SPRYp & L-asp & TUB $\beta 1$ & АСТВ & MSF1 & $18 \mathrm{~S}$ & GAPDH & CYP & MAPK & $28 \mathrm{~S}$ \\
\hline BestKeeper & SPRYp & L-asp & UBQ & TUB $\beta 1$ & TUB $\alpha$ & & & АСТВ & CYP & GADPH & $18 \mathrm{~S}$ & $28 \mathrm{~S}$ \\
\hline Comprehensive Ranking & UBQ & TUB $\alpha$ & SPRYp & L-asp & TUB $\beta 1$ & ACTB & MSF1 & YYP & GAPDH & MAPK & $18 \mathrm{~S}$ & $28 \mathrm{~S}$ \\
\hline \multicolumn{13}{|c|}{ RANKING ORDER UNDER COLD STRESS (BETTER-GOOD-AVERAGE) } \\
\hline geNorm & $\begin{array}{c}\text { MSF1 } \\
\text { SPRYp }\end{array}$ & & TUB $\alpha$ & ACTB & L-asp & UBQ & CYP & $28 \mathrm{~S}$ & GAPDH & MAPK & TUB $\beta 1$ & $18 \mathrm{~S}$ \\
\hline NormFinder & MSF1 & SPRYp & TUB $\alpha$ & ACTB & L-asp & UBQ & CYP & $28 \mathrm{~S}$ & MAPK & GAPDH & TUB $\beta 1$ & $18 \mathrm{~S}$ \\
\hline BestKee & GADPH & UBQ & L-asp & CYP & MSF1 & SPRYp & TUB $\alpha$ & MAPK & АCTB & $28 \mathrm{~S}$ & TUB $\beta 1$ & $18 \mathrm{~S}$ \\
\hline Comprehensive Ranking & MSF1 & SPRYp & TUB $\alpha$ & UBQ & L-asp & GAPDH & & & $28 \mathrm{~S}$ & & TUB $\beta 1$ & $18 \mathrm{~S}$ \\
\hline \multicolumn{13}{|c|}{ RANKING ORDER UNDER HOT STRESS (BETTER-GOOD-AVERAGE) } \\
\hline geNorm & $\begin{array}{l}\text { UBQ } \\
\text { MSF1 }\end{array}$ & & CYP & ACTB & TUB $\beta 1$ & $\mathrm{TUB} \alpha$ & L-asp & GAPDH & SPRYp & $18 \mathrm{~S}$ & $28 \mathrm{~S}$ & MAPK \\
\hline Norm & UBQ & MSF1 & CYP & TUB $\beta 1$ & ACTB & $\mathrm{TUB} \alpha$ & SPRYp & GAPDH & & & $28 \mathrm{~S}$ & MAPK \\
\hline Best & MSF1 & $\operatorname{TUB} \alpha$ & L-asp & GADPH & SPRYp & TUB $\beta 1$ & CYP & $18 \mathrm{~S}$ & ACTB & UBQ & MAPK & $28 \mathrm{~S}$ \\
\hline Comprehensive Ranking & MSF1 & UBQ & CYP & TUB $\alpha$ & TUB $\beta 1$ & ACTB & L-asp & APDH & SPRYp & $18 \mathrm{~S}$ & $28 \mathrm{~S}$ & MAPK \\
\hline \multicolumn{13}{|c|}{ RANKING ORDER UNDER ACID STRESS (BETTER-GOOD-AVERAGE) } \\
\hline geNorm & $\begin{array}{l}\text { SPRYp } \\
\text { MAPK }\end{array}$ & & MSF1 & TUB $\beta 1$ & $\mathrm{TUB} \alpha$ & $28 \mathrm{~S}$ & $18 \mathrm{~S}$ & GAPDH & ACTB & CYP & UBQ & L-asp \\
\hline NormFinder & MSF1 & TUB $\alpha$ & TUB $\beta 1$ & ACTB & MAPK & SPRYp & GAPDH & $28 \mathrm{~S}$ & CYP & $18 \mathrm{~S}$ & UBQ & L-asp \\
\hline BestKeeper & TUB $\beta 1$ & MAPK & SPRYp & MSF1 & $\mathrm{TUB} \alpha$ & L-asp & CYP & UBQ & ACTB & GADPH & $28 \mathrm{~S}$ & $18 \mathrm{~S}$ \\
\hline Comprehensive Ranking & MAPK & MSF1 & TUB $\beta 1$ & SPRYp & TUB $\alpha$ & ACTB7 & $28 \mathrm{~S}$ & GAPDH & CYP & $18 \mathrm{~S}$ & L-asp & UBQ \\
\hline \multicolumn{13}{|c|}{ RANKING ORDER UNDER ALKALI STRESS (BETTER-GOOD-AVERAGE) } \\
\hline geNorm & $\begin{array}{c}\text { MSF1 } \\
\text { MAPK }\end{array}$ & & $18 \mathrm{~S}$ & L-asp & CYP & UBQ & TUB $\alpha$ & TUB $\beta 1$ & SPRYp & GAPDH & $28 \mathrm{~S}$ & $\mathrm{ACTB}$ \\
\hline & & L-asp & CYP & UBQ & MSF1 & MAPK & & TUB $\beta 1$ & & GAPDH & $28 \mathrm{~S}$ & ACTB \\
\hline BestKeeper & L-asp & MSF1 & MAPK & SPRYp & GADPH & CYP & TUB $\alpha$ & UBQ & TUB $\beta 1$ & $18 \mathrm{~S}$ & ACTB & $28 \mathrm{~S}$ \\
\hline Comprehensive Ranking & L-asp & MSF1 & MAPK & $18 \mathrm{~S}$ & CYP & UBQ & SPRYp & TUB $\alpha$ & GAPDH & TUB $\beta 1$ & $28 \mathrm{~S}$ & ACTB \\
\hline \multicolumn{13}{|c|}{ RANKING ORDER UNDER DIFFERENT STAGES (BETTER-GOOD-AVERAGE) } \\
\hline geNorm & $\begin{array}{l}\text { TUB } \beta 1 \\
\text { MAPK }\end{array}$ & & TUB $\alpha$ & L-asp & $18 \mathrm{~S}$ & GAPDH & SPRYp & MSF1 & CYP & $28 \mathrm{~S}$ & UBQ & ACTB \\
\hline NormFinder & L-asp & TUB $\beta 1$ & MAPK & TUB $\alpha$ & GAPDH & $18 \mathrm{~S}$ & SPRYp & MSF1 & CYP & $28 \mathrm{~S}$ & UBQ & ACTB \\
\hline BestKeeper & SPRYp & GADPH & L-asp & CYP & UBQ & MAPK & MSF1 & $\mathrm{TUB} \alpha$ & TUB $\beta 1$ & $18 \mathrm{~S}$ & $28 \mathrm{~S}$ & $\mathrm{ACTB}$ \\
\hline Comprehensive Ranking & L-asp & TUB $\beta 1$ & MAPK & SPRYp & GAPDH & $\operatorname{TUB} \alpha$ & $18 \mathrm{~S}$ & CYP & MSF1 & UBQ4 & $28 \mathrm{~S}$ & ACTB \\
\hline \multicolumn{13}{|c|}{ RANKING ORDER UNDER ALL SAMPLES (BETTER-GOOD-AVERAGE) } \\
\hline geNorm & $\begin{array}{l}\text { TUB } \alpha \\
\text { SPRYp }\end{array}$ & & L-asp & CYP & GAPDH & MSF1 & UBQ & $28 \mathrm{~S}$ & MAPK & TUB $\beta 1$ & $18 \mathrm{~S}$ & ACTB \\
\hline NormFinder & SPRYp & TUB $\alpha$ & MSF1 & L-asp & CYP & GAPDH & MAPK & UBQ & TUB $\beta 1$ & $28 \mathrm{~S}$ & $18 \mathrm{~S}$ & $\mathrm{ACTB}$ \\
\hline BestKeeper & CYP & L-asp & MSF1 & MAPK & GADPH & ACTB & SPRYp & TUB $\beta 1$ & TUB $\alpha$ & UBQ & $18 \mathrm{~S}$ & $28 \mathrm{~S}$ \\
\hline Comprehensive Ranking & SPRYp & TUB $\alpha$ & CYP & L-asp & MSF1 & GAPDH & MAPK & UBQ & TUB $\beta 1$ & ACTB & $28 \mathrm{~S}$ & $18 \mathrm{~S}$ \\
\hline
\end{tabular}



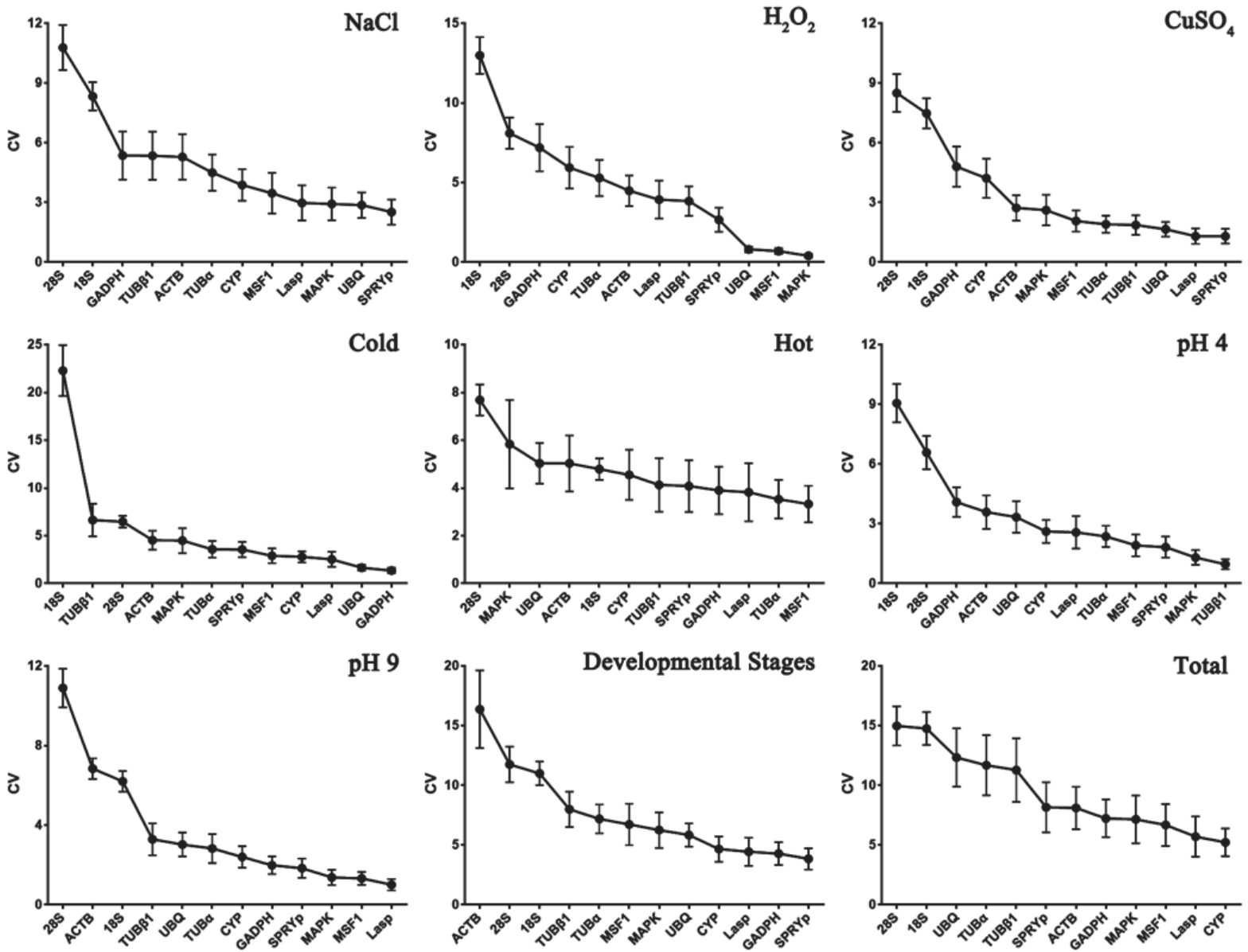

FIGURE 3: Expression stability of $\mathbf{1 2}$ V. volvacea reference genes as calculated by BestKepper. The CVs and SDs of the candidate reference genes were used to evaluate the stability of the candidate reference genes in all tested conditions. The gene with the lowest CV and SD was considered the most stably expressed, which is on the right, while the least stable gene is on the left. The treatments and group classifications are indicated in the figure.

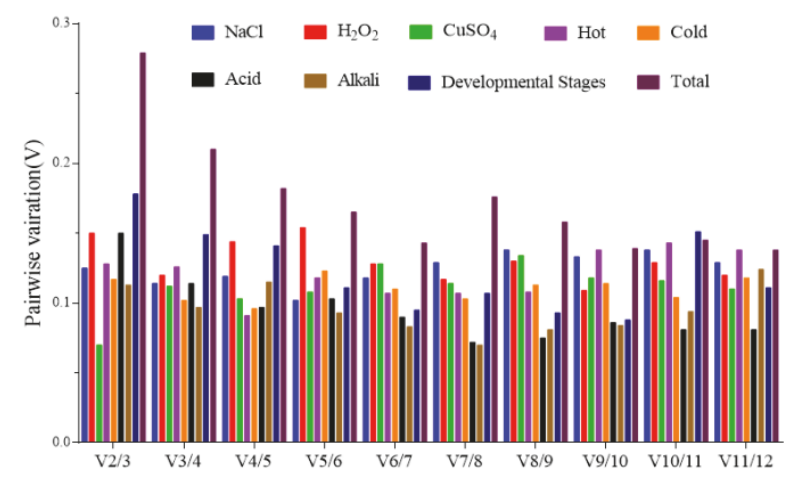

FIGURE 4: Determination of the optimal number of reference genes for normalization by pairwise variation using geNorm. Pairwise variation $(\mathrm{Vn} / \mathrm{n}+1)$ analysis of the normalization factors $(\mathrm{NFn}$ and $\mathrm{NFn}+1)$ was performed for all samples. Different conditions are included and marked in square frames with different colors. "Total group" refers to all samples. V is the variation value, where $>0.15$ indicates that an additional reference gene does not improve normalization. the resulting data, as the use of unstable reference genes could yield inaccurate results. Therefore, numerous studies have been conducted to investigate reference gene stability under different conditions $[29,30,37,38]$. In this present study, the stability of expression of 12 candidate $V$. volvacea reference genes was systematically analyzed using geNorm, NormFinder, and BestKeeper in the presence of salt $(\mathrm{NaCl})$, oxidative $\left(\mathrm{H}_{2} \mathrm{O}_{2}\right)$, metal $\left(\mathrm{CuSO}_{4}\right)$, acid $(\mathrm{pH} 4)$, alkali $(\mathrm{pH}$ 9), cold $\left(4^{\circ} \mathrm{C}\right)$, and heat stress $\left(42^{\circ} \mathrm{C}\right)$, and during different developmental stages. Based on their differential stability, it was found different genes were optimal as references under different conditions.

In this study, the 12 reference genes were first cloned from cDNA template, although PCR was also conducted using genomic DNA as template. As shown in Fig. S1, the primers were specific and the PCR products from different templates of different lengths. Primer pair specificity was also confirmed by melting curve analysis (Fig. S2), while amplification efficiency was calculated based on the slopes of the standard curves. The R2 $>0.99$ and E-values ranged 


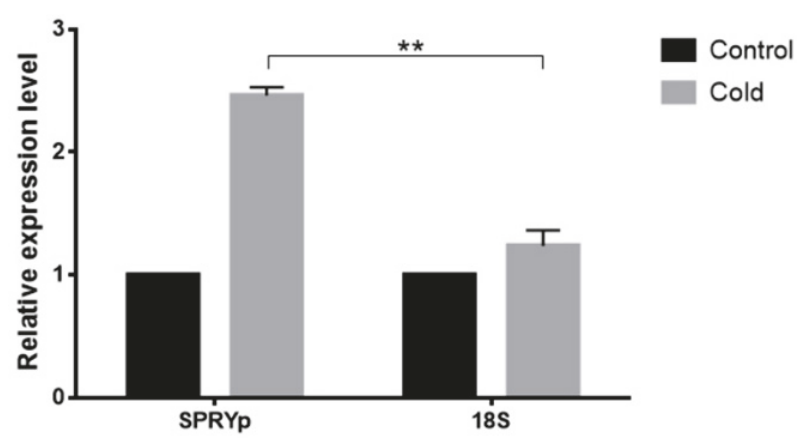

(a)

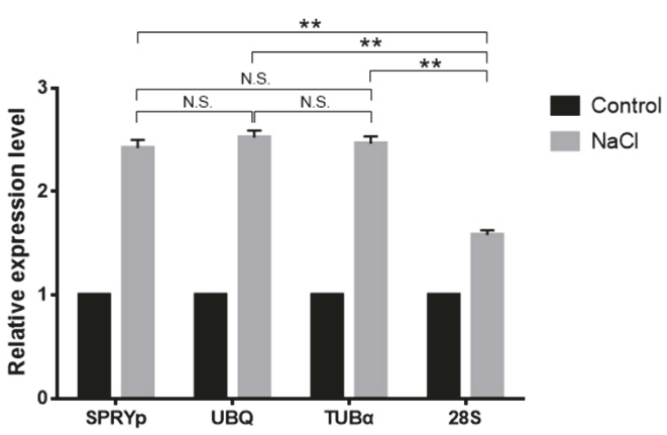

(b)

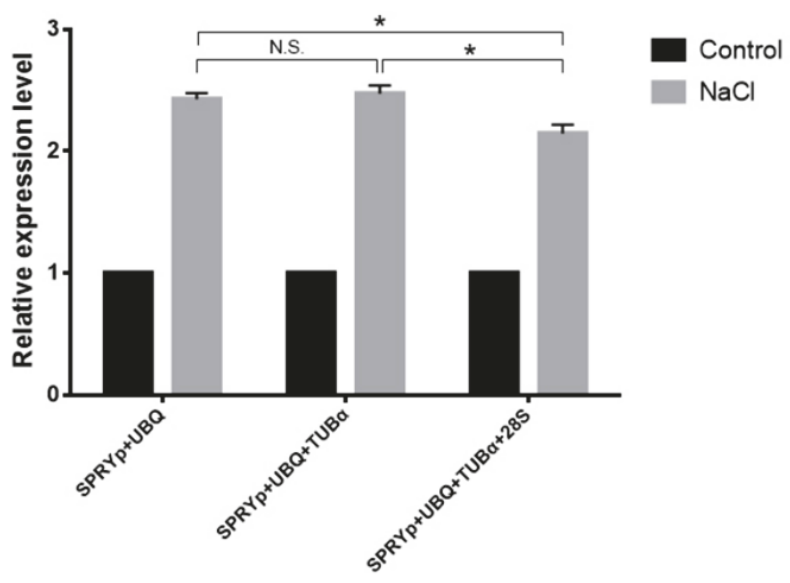

(c)

FIGURE 5: Validation of reference gene quality. Relative G6PDH expression levels were normalized using candidate reference genes under different conditions. (a) Expression levels were measured in the presence of (a) $\mathrm{CuSO}_{4}$ and (b) $\mathrm{NaCl}$ and normalized using the most and least stable reference genes. SPRYp, UBQ, and TUB $\alpha$ represent the three in five most stable reference genes and $28 S$ the least stable gene in Cold and $\mathrm{NaCl}$. (c) Expression levels were normalized using different combinations of reference genes. Data are displayed as mean \pm standard error of the mean. Statistical analyses were performed using Student's t-test to compare two reference genes or combinations of reference genes for normalization. ${ }^{*} \mathrm{P}<0.05$; ${ }^{* *} \mathrm{P}<0.01$; N.S.: no significant difference.

from 92.34 to $109.23 \%$ (Table 1 and Fig. S3), where there was a good linear relationship based on the standard curves and acceptable PCR conditions.

The expression levels of the selected genes were also investigated and the mean Cps are listed in Figure 1. The average expression levels ranged from 9.37 to 29.56 , consistent with previous studies $[29,38]$. Because moderate expression levels (e.g., Cp of 15 to 30 ) yield accurate normalization [39], the genes selected in this study were found to be sufficient for experimental needs. Low Cps correspond with high expression levels; therefore, some candidate genes in this study were abundantly distributed in $V$. volvacea. For instance, $U B Q$ had a mean $\mathrm{Cp}$ value of 19 in $V$. volvacea, but a Cp of up to 27 in Ganoderma Lucidum [40, 41]. A narrow distribution range indicates low variability. Therefore, the variation in Cps observed in this study indicates $C Y P$ is the most optimal reference gene and MAPK is the least. However, these results are somewhat inconsistent with those from geNorm and NormFinder (Figure 2 and Table 2). Based on the differences in the stability and expression levels of the candidate reference genes, stability and expression analyses using different methods need to be combined.

To increase accuracy when analyzing candidate gene stability, three Excel-based programs were used as previously described [29, 33-35]. Because different types of software have distinct methods of ranking candidate gene stability and there might be differences in results, at least two methods had to be used to analyze the data. In addition, because reference gene expression stability differs under different conditions, gene expression was assessed in the presence of salt, oxidative, metal, acid-base, and temperature stresses and during different developmental stages. The treatments conducted in the study included nearly all used in similar studies and, therefore, this present study was a systematic assessment of gene stability $[9,14,29,42]$.

According to the geNorm analysis, $T U B \alpha$ and SPRYP were the two most stable reference genes for all samples and conditions, which is consistent with the NormFinder, but not BestKeeper, results. For BestKeeper, CYP and L-asp had lower CVs and were the most stable reference genes. This may be 
because the geNorm and NormFinder analyses performed calculations of stability in a similar manner, while BestKeeper used $\mathrm{CV} \pm \mathrm{SD}$ to rank stability. This phenomenon was also reported by Zhao and Tian in their studies [14, 30]. However, there tended to be consistency when comparing the five most stable reference genes. For example, for $\mathrm{NaCl}$-induced stress, geNorm, NormFinder, and BestKeeper analyses found $U B Q>$

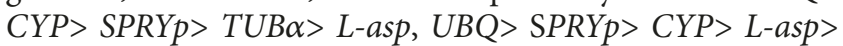
$T U B \alpha$, and $S P R Y p>U B Q>M A P K>L$-asp> MSF1, respectively. Furthermore, when normalized using $S P R Y p, U B Q$, and $T U B \alpha$, there were no significance differences in $G 6 P D H$ expression (Figure 5(b)). Therefore, predicting reference gene stability using three types of software was sufficient and is a good strategy for selecting reference genes for normalization [43-45]. For example, when the three types of analyses were combined, SPRYp, TUB,$M S F$ 1, CYP, and L-asp were the most stable reference genes under the different conditions and were easily at the top of the lists in Figures 2 and 3 and Table 2, where one of these was the optimal reference gene in at least one condition. However, the candidate genes with low stability could also be used for normalization. For example, while GAPDH ranked nearly last among the candidate genes, it had a low $C V$ and high expression under cold stress, making it a satisfactory reference under this specific condition. There have also been numerous studies indicating that GAPDH is among the most stably expressed genes and is usually used to analyze gene expression [46-49]. Overall, experimental conditions and expression abundance have equal importance when choosing a suitable reference gene.

To the best of our knowledge, this present study was the second to survey $V$. volvacea reference gene stability and provides a basis for further exploration of metabolism and regulation in response to environmental stresses. This study focused on different developmental stages and abiotic stresses $\left(\mathrm{NaCl}, \mathrm{CuSO}_{4}, \mathrm{H}_{2} \mathrm{O}_{2}, \mathrm{HCl}, \mathrm{NaOH}\right.$, heat, and cold), while Tao et al. [29] performed the first study on $V$. volvacea internal control genes for different strains, fruiting body developmental stages, and growth stages. Interestingly, the results of these two studies were very similar as $S P R Y p, T U B \alpha$, $C Y P, L$-asp, and $M S F 1$ were the most stable reference genes in this present study, while SPRYp, Ras, Vps 26, and ACTB were most stable in Tao's study. Ras and Vps 26 were not included in the 12 candidate genes we selected, but $L$-asp, TUB $\alpha$, and $M S F 1$, which were assessed in this study, ranked among the top in Tao's study, supporting our results. Conversely, ACTB was among the least stable reference genes in our study, which is inconsistent with Tao et al. [29]. This may be a result of different experimental conditions, because no reference gene was universally stable. Ultimately, the choice of reference gene will depend on the specific set of experiments, to which our efforts are complementary.

To determine how many reference genes are needed for accurate analysis, "pairwise variation (V)" was calculated in geNorm. A V score of 0.15 was used as a cut-off according to the manufacturer's instructions, below which the inclusion of an additional reference gene was not required [33]. Based on this, the optimal numbers of reference genes were calculated and are listed in Figure 3. When analyzing the 9 experimental groups, $7 \mathrm{had}$ a $\mathrm{V}$ score $<0.15$, indicating there was no need for the use of a third reference gene. This is consistent with work by Zhao et al. [14], who saw no notable differences when two or three reference genes were used for normalization, and $\mathrm{Ma}$ et al. [9], who evaluated different combinations of reference genes for normalization. However, when the V score $>0.15$, an additional reference gene is recommended. As previously shown, when one of least stably expressed reference genes, $A C T B$, was combined with other stable genes, the results appeared credible [50, 51]. This also indicates that the proposed $\mathrm{V}$ of 0.15 value should not be considered a strict cut-off [33], which is in line with several reports that used higher $\mathrm{V}$ values $[39,52]$.

\section{Conclusions}

When characterizing gene expression, the most commonly used method is RT-qPCR, where a suitable reference gene is necessary for normalization of results. In this present study, 12 candidate reference genes in $V$. volvacea were investigated to determine the most stably expressed under different conditions. Analysis of gene expression stability using geNorm, NormFinder, and BestKepper revealed that SPRYp,TUB $\alpha$, $C Y P, L$-asp, and MSF1 were the most stably expressed reference genes and were optimal for normalization (Table 3). By contrast, $18 \mathrm{~S}$ and $28 \mathrm{~S}$ were the least stably expressed genes. The optimal number of reference genes for normalization was also calculated based on pairwise variation $(\mathrm{Vn} / \mathrm{Vn}+1)$ using geNorm and it was found the two most stable reference genes were sufficient for normalization under most conditions. Since gene expression varies in different experiment conditions, this study is the first survey of reference gene stability and providing a basis for further research in V. volvacea, it also provides guidelines for obtaining more accurate RT-qPCR results for other edible fungal species.

\section{Data Availability}

All the figures and tables used to support the findings of this study are included within the article and supplementary information files.

\section{Conflicts of Interest}

The authors declare no conflicts of interest.

\section{Authors' Contributions}

Jiang Qian and Yingnv Gao contributed equally to this work.

\section{Acknowledgments}

This study was partly supported by the Shanghai Municipal Agricultural Commission, China [Hu nong qing zi (2017) no. 1-14], Yong Elite Scientists Sponsorship Program by CAST, the National Natural Science Foundation of China (Grant no. 81573564, no. 81703637), Natural Science Fund in Jiangsu Province (BK20170736), and the Priority Academic Program Development of Jiangsu Higher Education Institutions. 


\section{Supplementary Materials}

Fig. S1: agarose gel (1\%) electrophoresis of the 12 candidate reference genes. Fig. S2: melt curves for the 12 candidate reference genes. Fig. S3: standard curves for the 12 candidate reference genes. Table S1: raw $\mathrm{Cp}$ values for $V$. volvacea. (Supplementary Materials)

\section{References}

[1] H. Engel, C. Kueppers, M. Koenig, and D. Loeffert, "Successful gene expression analysis by multiplex, real-time, one-step RTPCR, irrespective of the targets amplified," BioTechniques, vol. 43, no. 2, pp. 230-231, 2007.

[2] S. Derveaux, J. Vandesompele, and J. Hellemans, "How to do successful gene expression analysis using real-time PCR," Methods, vol. 50, no. 4, pp. 227-230, 2010.

[3] G. Woźniak, R. Herok, R. Jaksik et al., "Cell-cycle gene expression analysis using real time PCR in locally advanced squamous-cell head and neck cancer," Advances in Medical Sciences, vol. 61, no. 2, pp. 293-299, 2016.

[4] R. C. Edmunds, J. K. McIntyre, J. Adam Luckenbach, D. H. Baldwin, and J. P. Incardona, "Toward enhanced MIQE compliance: Reference residual normalization of qPCR gene expression data," Journal of Biomolecular Techniques, vol. 25, no. 2, pp. 54-60, 2014.

[5] D. J. P. Rocha, C. S. Santos, and L. G. C. Pacheco, "Bacterial reference genes for gene expression studies by RT-qPCR: survey and analysis," Antonie van Leeuwenhoek-Journal of Microbiology, vol. 108, no. 3, pp. 685-693, 2015.

[6] S. Taylor, "MIQE Case Study - Effect of RNA Sample Quality and Reference Gene Stability on Gene Expression Data," Bio, 2011, tech note 6245 .

[7] F. Bollmann, I. Casper, J. Henke, and A. Pautz, "qRT-PCR: A method and its difficulties," Naunyn-Schmiedeberg's Archives of Pharmacology, vol. 385, no. 10, pp. 949-951, 2012.

[8] D. Dušanić, L. Bolha, M. Narat, and I. Oven, "Setting up a gene expression study for tissue cells by method of quantitative realtime PCR," Acta agriculturae Slovenica, vol. 100, no. 1, pp. 19-28, 2012.

[9] R. Ma, S. Xu, Y. Zhao, B. Xia, and R. Wang, "Selection and Validation of Appropriate Reference Genes for Quantitative Real-Time PCR Analysis of Gene Expression in Lycoris aurea," Frontiers in Plant Science, vol. 7, 2016.

[10] W. Li, L. Zhang, Y. Zhang, G. Wang, D. Song, and Y. Zhang, "Selection and validation of appropriate reference genes for quantitative real-time PCR normalization in staminate and perfect flowers of andromonoecious Taihangia rupestris," Frontiers in Plant Science, vol. 8, 2017.

[11] X. Li, D. Zhang, H. Li et al., "Characterization of reference genes for RT-qPCR in the desert moss Syntrichia caninervis in response to abiotic stress and desiccation/rehydration," Frontiers in Plant Science, vol. 6, 2015.

[12] H. Zhuang, Y. Fu, W. He, L. Wang, and Y. Wei, "Selection of appropriate reference genes for quantitative real-time PCR in Oxytropis ochrocephala Bunge using transcriptome datasets under abiotic stress treatments," Frontiers in Plant Science, vol. 6, no. JUNE, 2015.

[13] T. Czechowski, M. Stitt, T. Altmann, M. K. Udvardi, and W.-R. Scheible, "Genome-wide identification and testing of superior reference genes for transcript normalization in arabidopsis," Plant Physiology, vol. 139, no. 1, pp. 5-17, 2005.
[14] Y. Zhao, J. Luo, S. Xu et al., "Selection of reference genes for gene expression normalization in peucedanum praeruptorum Dunn under abiotic stresses, hormone treatments and different tissues," PLoS ONE, vol. 11, no. 3, Article ID e0152356, 2016.

[15] L. Meng, J. Yan, B. Xie et al., "Genes encoding FAD-binding proteins in Volvariella volvacea exhibit differential expression in homokaryons and heterokaryons," Microbiological Research, vol. 168, no. 8, pp. 533-546, 2013.

[16] T. Kumhomkul and T. Panich-Pat, "Lead accumulation in the straw mushroom, volvariella volvacea, from lead contaminated rice straw and stubble," Bulletin of Environmental Contamination and Toxicology, vol. 91, no. 2, pp. 231-234, 2013.

[17] B. Chen, F. Gui, B. Xie et al., "Composition and Expression of Genes Encoding Carbohydrate-Active Enzymes in the StrawDegrading Mushroom Volvariella volvacea," PLoS ONE, vol. 8, no. 3, Article ID e58780, 2013.

[18] P. Diamantopoulou, S. Papanikolaou, G. Aggelis, and A. Philippoussis, "Adaptation of Volvariella volvacea metabolism in high carbon to nitrogen ratio media," Food Chemistry, vol. 196, Article ID 18109, pp. 272-280, 2016.

[19] Y. Lu, L. Lian, L. Guo et al., "The Accordant Trend of Both Parameters (rgs Expression and cAMP Content) Follows the Pattern of Development of Fruiting Body in Volvariella volvacea," Current Microbiology, vol. 71, no. 5, pp. 579-584, 2015.

[20] T. Lian, T. Yang, G. Liu, J. Sun, and C. Dong, "Reliable reference gene selection for Cordyceps militaris gene expression studies under different developmental stages and media," FEMS Microbiology Letters, vol. 356, no. 1, pp. 97-104, 2014.

[21] O. Zarivi, P. Cesare, A. M. Ragnelli et al., "Validation of reference genes for quantitative real-time PCR in Périgord black truffle (Tuber melanosporum) developmental stages," Phytochemistry, vol. 116, no. 1, pp. 78-86, 2015.

[22] L. Song, T. Li, L. Fan, X.-Y. Shen, and C.-L. Hou, "Identification and Evaluation of Reliable Reference Genes in the Medicinal Fungus Shiraia bambusicola," Current Microbiology, vol. 72, no. 4, pp. 444-449, 2016.

[23] Q. Q. Li, J. Skinner, and J. E. Bennett, "Evaluation of reference genes for real-time quantitative PCR studies in Candida glabrata following azole treatment," BMC Molecular Biology, vol. 13, article no. 22, 2012.

[24] A. Llanos, J. M. François, and J.-L. Parrou, "Tracking the best reference genes for RT-qPCR data normalization in filamentous fungi," BMC Genomics, vol. 16, no. 1, article no. 71, 2015.

[25] K. D. Cusick, L. A. Fitzgerald, R. K. Pirlo, A. L. Cockrell, E. R. Petersen, and J. C. Biffinger, "Selection and evaluation of reference genes for expression studies with quantitative PCR in the model fungus neurospora crassa under different environmental conditions in continuous culture," PLoS ONE, vol. 9, no. 12, Article ID e112706, 2014.

[26] D. Hirschburger, M. Müller, R. T. Voegele, and T. Link, "Reference genes in the Pathosystem phakopsora pachyrhizi/ soybean suitable for normalization in transcript profiling," International Journal of Molecular Sciences, vol. 16, no. 9, pp. 23057-23075, 2015.

[27] S. G. Kunjeti, G. Iyer, E. Johnson et al., "Identification of Phakopsora pachyrhizi candidate effectors with virulence activity in a distantly related pathosystem," Frontiers in Plant Science, vol. 7, no. 2016, 2016.

[28] R. Castanera, L. López-Varas, A. Pisabarro, and L. Ramíre, "Validation of reference genes for transcriptional analyses in Pleurotus ostreatus by using reverse transcription-quantitative 
PCR," Applied and Environmental Microbiology, vol. 81, no. 12, pp. 4120-4129, 2015.

[29] Y. Tao, A. F. Van Peer, Q. Huang et al., "Identification of novel and robust internal control genes from Volvariella volvacea that are suitable for RT-qPCR in filamentous fungi," Scientific Reports, vol. 6, 2016.

[30] C. Tian, Q. Jiang, F. Wang, G.-L. Wang, Z.-S. Xu, and A.-S. Xiong, "Selection of suitable reference genes for qPCR normalization under abiotic stresses and hormone stimuli in carrot leaves," PLoS ONE, vol. 10, no. 2, Article ID e0117569, 2015.

[31] Y. Lin, C. Zhang, H. Lan et al., "Validation of potential reference genes for qPCR in maize across abiotic stresses, hormone treatments, and tissue types," PLoS ONE, vol. 9, no. 5, Article ID e95445, 2014.

[32] G. Thiribhuvanamala, S. Krishnamoorthy, K. Manoranjitham et al., "Improved techniques to enhance the yield of paddy straw mushroom (Volvariella volvacea) for commercial cultivation," African Journal of Biotechnology, vol. 11, no. 64, 2012.

[33] Y. M. Schlotter, E. Z. Veenhof, B. Brinkhof et al., "A GeNorm algorithm-based selection of reference genes for quantitative real-time PCR in skin biopsies of healthy dogs and dogs with atopic dermatitis," Veterinary Immunology and Immunopathology, vol. 129, no. 1-2, pp. 115-118, 2009.

[34] C. L. Andersen, J. L. Jensen, and T. F. Ørntoft, "Normalization of real-time quantitative reverse transcription-PCR data: a modelbased variance estimation approach to identify genes suited for normalization, applied to bladder and colon cancer data sets," Cancer Research, vol. 64, no. 15, pp. 5245-5250, 2004.

[35] M. W. Pfaffl, A. Tichopad, C. Prgomet, and T. P. Neuvians, "Determination of stable housekeeping genes, differentially regulated target genes and sample integrity: bestKeeper-excelbased tool using pair-wise correlations," Biotechnology Letters, vol. 26, no. 6, pp. 509-515, 2004.

[36] X. Xiao, J. Ma, J. Wang, X. Wu, P. Li, and Y. Yao, "Validation of suitable reference genes for gene expression analysis in the halophyte salicornia europaea by real-time quantitative pcr," Frontiers in Plant Science, vol. 5, pp. 1-11, 2015.

[37] J. Su, R. Zhang, J. Dong, and C. Yang, "Evaluation of internal control genes for qRT-PCR normalization in tissues and cell culture for antiviral studies of grass carp (Ctenopharyngodon idella)," Fish and Shellfish Immunology, vol. 30, no. 3, pp. 830835, 2011.

[38] C. Zhang, T. Li, C.-L. Hou, and X.-Y. Shen, "Selection of reference genes from Shiraia bambusicola for RT-qPCR analysis under different culturing conditions," AMB Express, vol. 7, no. 1, 2017.

[39] H. Wan, Z. Zhao, C. Qian, Y. Sui, A. A. Malik, and J. Chen, "Selection of appropriate reference genes for gene expression studies by quantitative real-time polymerase chain reaction in cucumber," Analytical Biochemistry, vol. 399, no. 2, pp. 257-261, 2010.

[40] J. Xu, Z. Xu, Y. Zhu et al., "Identification and evaluation of reference genes for qRT-PCR normalization in ganoderma lucidum," Current Microbiology, vol. 68, no. 1, pp. 120-126, 2014.

[41] Z. Xu, J. Xu, A. Ji et al., "Genome-wide selection of superior reference genes for expression studies in Ganoderma lucidum," Gene, vol. 574, no. 2, Article ID 40772, pp. 352-358, 2015.

[42] L. Niu, Y.-B. Tao, M.-S. Chen et al., "Selection of reliable reference genes for gene expression studies of a promising oilseed crop, plukenetia volubilis, by real-time quantitative PCR," International Journal of Molecular Sciences, vol. 16, no. 6, pp. 1251312530, 2015.
[43] A. R. Paolacci, O. A. Tanzarella, E. Porceddu, and M. Ciaffi, "Identification and validation of reference genes for quantitative RT-PCR normalization in wheat," BMC Molecular Biology, vol. 10, article 11, 2009.

[44] M. Expósito-Rodríguez, A. A. Borges, A. Borges-Pérez, and J. A. Pérez, "Selection of internal control genes for quantitative real-time RT-PCR studies during tomato development process," BMC Plant Biology, vol. 8, article 131, 2008.

[45] X. Wang, Y. Fu, L. Ban et al., "Selection of reliable reference genes for quantitative real-time RT-PCR in alfalfa," Genes \& Genetic Systems, vol. 90, no. 3, p. 175, 2015.

[46] C. F. Barsalobres-Cavallari, F. E. Severino, M. P. Maluf, and I. G. Maia, "Identification of suitable internal control genes for expression studies in Coffea arabica under different experimental conditions," BMC Molecular Biology, vol. 10, article 1, 2009.

[47] P. Murthi, E. Fitzpatrick, A. J. Borg, S. Donath, S. P. Brennecke, and B. Kalionis, "GAPDH, 18S rRNA and YWHAZ are Suitable Endogenous Reference Genes for Relative Gene Expression Studies in Placental Tissues from Human Idiopathic Fetal Growth Restriction,” Placenta, vol. 29, no. 9, pp. 798-801, 2008.

[48] O. Giricz, J. L. Lauer-Fields, and G. B. Fields, “The normalization of gene expression data in melanoma: Investigating the use of glyceraldehyde 3-phosphate dehydrogenase and $18 \mathrm{~S}$ ribosomal RNA as internal reference genes for quantitative realtime PCR," Analytical Biochemistry, vol. 380, no. 1, pp. 137-139, 2008.

[49] N. Podevin, A. Krauss, I. Henry, R. Swennen, and S. Remy, "Selection and validation of reference genes for quantitative RT-PCR expression studies of the non-model crop Musa," Molecular Breeding, vol. 30, no. 3, pp. 1237-1252, 2012.

[50] K. Majidzadeh-A, R. Esmaeili, and N. Abdoli, “TFRC and ACTB as the best reference genes to quantify Urokinase Plasminogen Activator in breast cancer," BMC Research Notes, vol. 4, 2011.

[51] M. Timmer, G. Roehn, A. Koch et al., "ACTB and SDHA are suitable endogenous reference genes under different treatment regimens for gene expression studies in human astrocytomas using quantitative real-time reverse-transcription-polymerase chain reaction," Scientific Meeting and Education Day of the, pp. 12-12, 2012.

[52] A. De Ketelaere, K. Goossens, L. Peelman, and C. Burvenich, "Technical note: Validation of internal control genes for gene expression analysis in bovine polymorphonuclear leukocytes," Journal of Dairy Science, vol. 89, no. 10, pp. 4066-4069, 2006. 


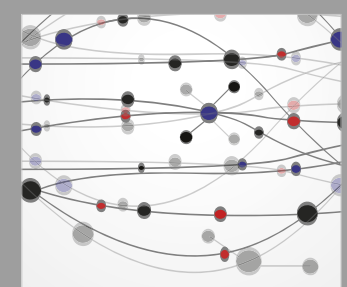

The Scientific World Journal
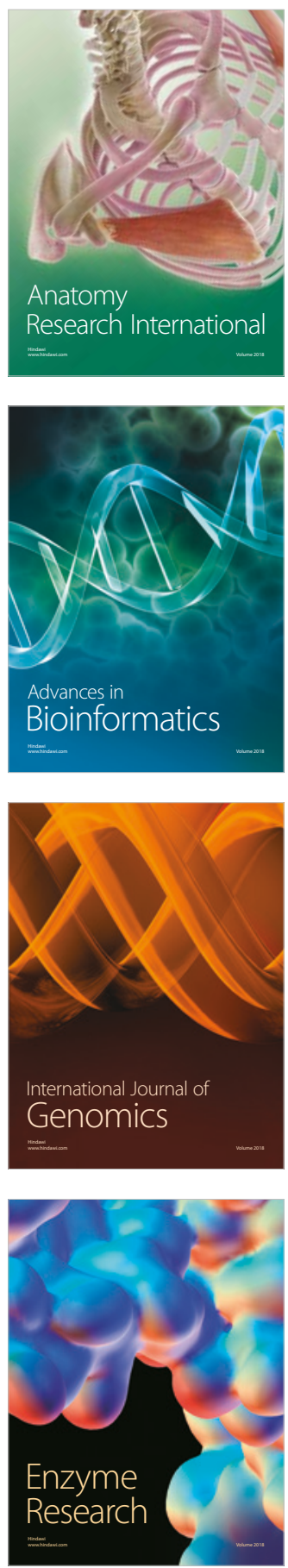
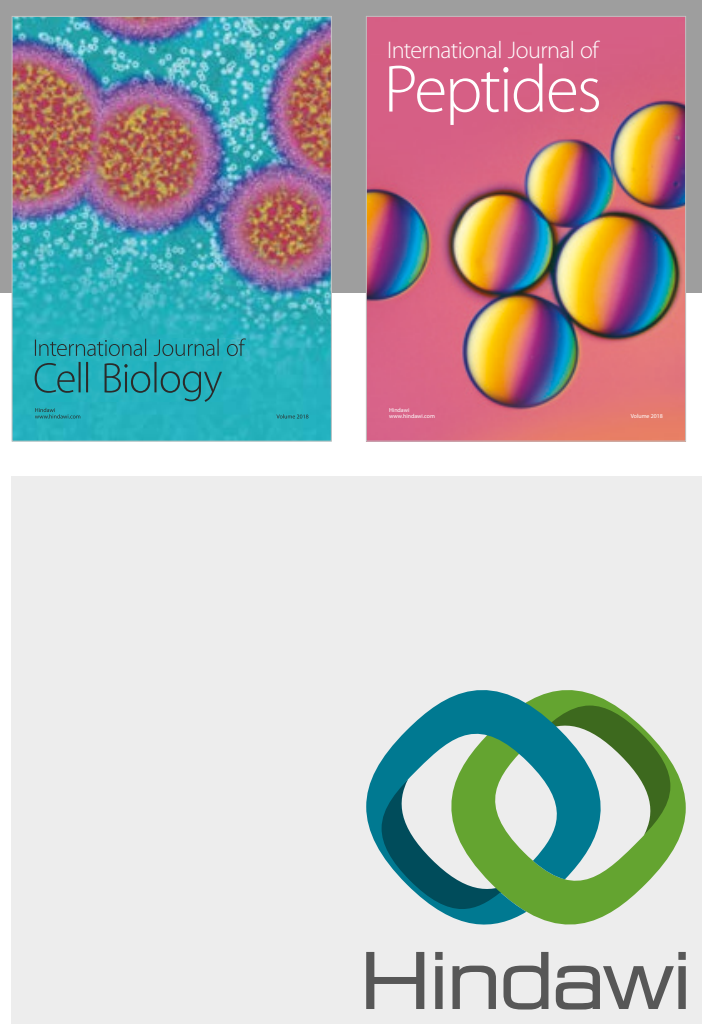

Submit your manuscripts at

www.hindawi.com
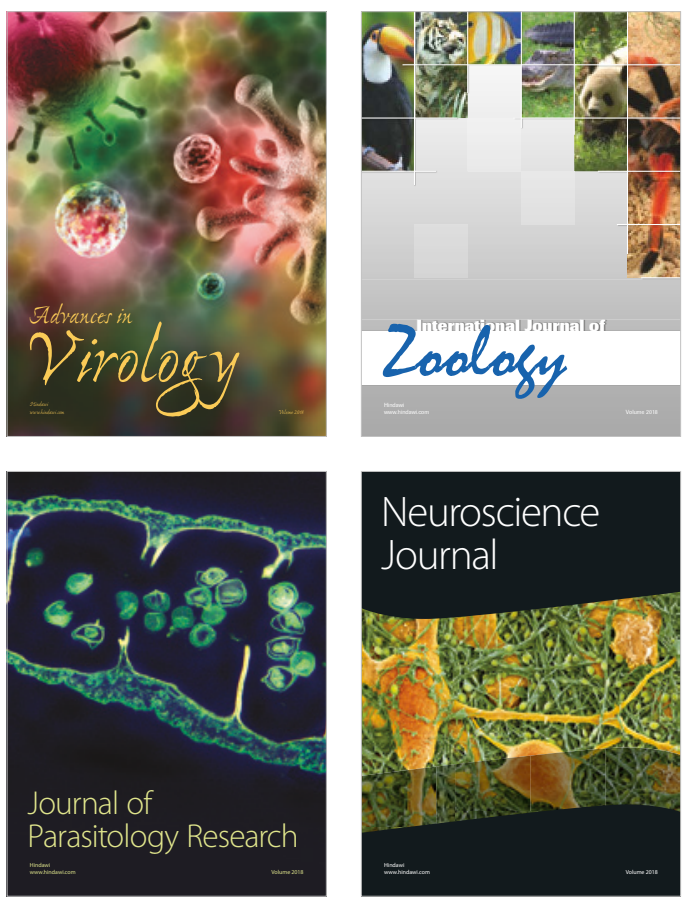
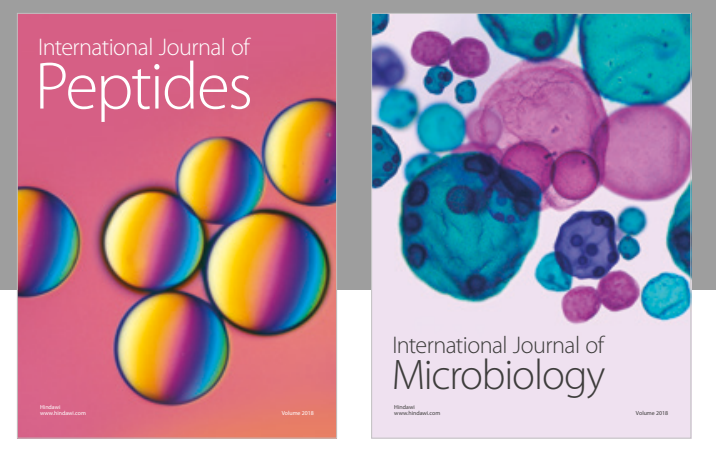

nternational Journal of Microbiology
Journal of
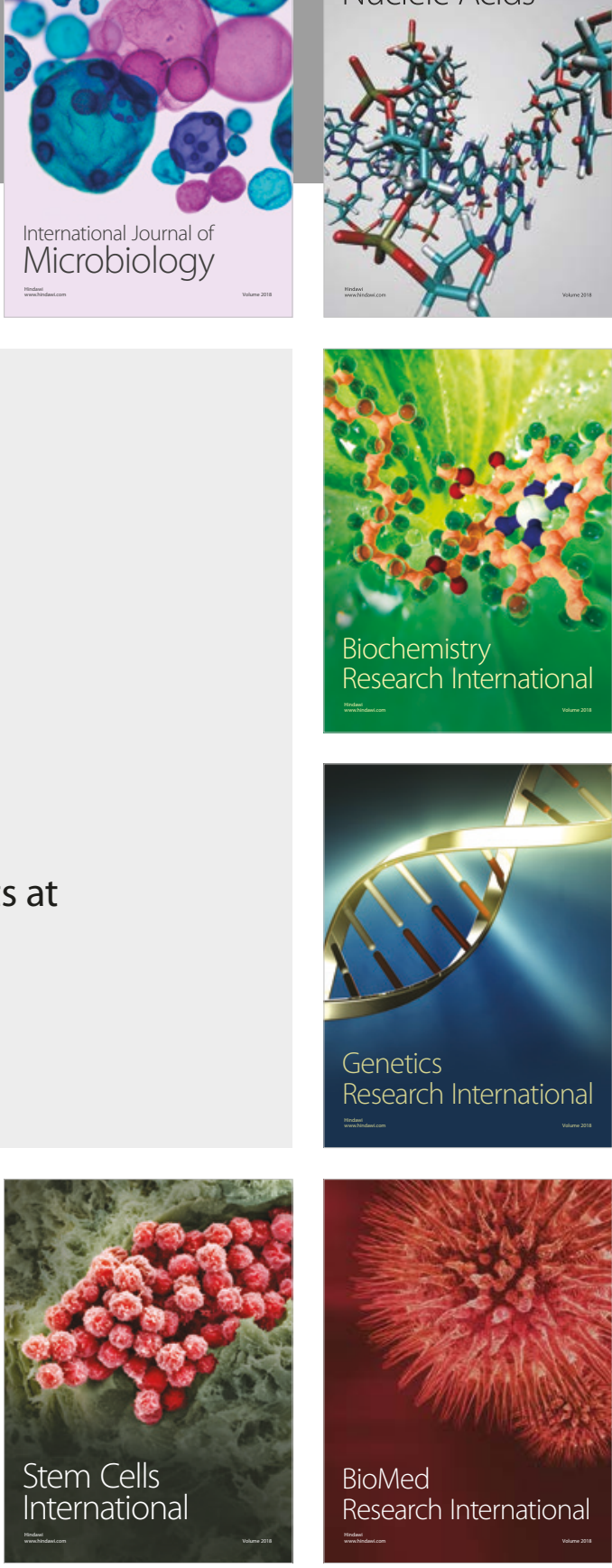
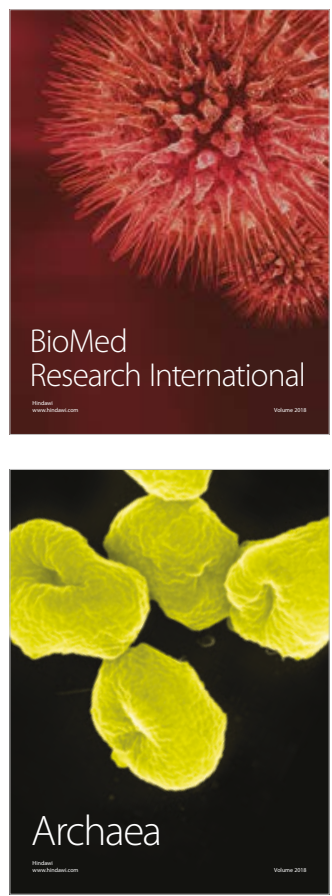